Journal of Agricultural, Environmental and Veterinary Sciences

Volume (5), Issue (3): 30 Sep 2021

P: 94 - 105

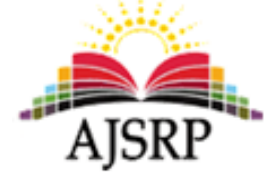

ISSN: 2522- 3364
مجلة العلوم الزراعية

والبيئية والبيطرية

المجلد (5)، العدد (3): 30 سبتمبر 2021م

ص: 94 - 105

\title{
Natural Feeding and Description of Clausocalanus furcatus Order Calanoida (Copepoda) in the coastal waters of Baniyas City (Eastern Mediterranean)
}

\author{
Wassim Mahmoud Mayya \\ Kamal Salem Al- Hanoun \\ Faculty of Sciences || Tishreen University || Syria
}

\begin{abstract}
This study, included the feeding of Clausocalanus furcatus of crustacean zooplankton (Calanoida), by studying the structure of the mandible and the gut content of this previous species to determine their favorite food. 93 samples have been collected vertically in period between March and October 2020. The samples were also accompanied with different hydrophysical and hydrochemical measurements in three regions that differ from each other with their environmental properties. The number of members of (C.furcatus) that were studied reached (64) individuals, of which (44) are female and (20) are male. On the other hand, determining the morphology, studying its structure, and knowing the content of the gut of the aforementioned species helped in expanding knowledge about the conditions and strategies of feeding it under the influence of environmental factors. The number of algae species (phytoplankton) that C.furcatus fed reached (9) species, of which (6) belong to the Dinophyceae, (2) species to Bacillariophyceae earth, and (1) only one species to the group Cryptophyceae. The highest average number of Dinophyceae was (1755), followed by Bacillariophyceae (505) individuals, then the group of Cryptophyceae (189) individuals.
\end{abstract}

Keywords: Natural Feeding, Mandible, Gut Content, Hydrophysical and Hydrochemical Measurements, Feeding Strategies.

\section{التغذية الطبيعية ووصف النوع Cyclopoidasocalanus furcatus رتبة)

$$
\text { في المياه الشاطئية لمدينة بانياس (شرق المتوسط) وفيه (Copepoda) }
$$

\author{
وسيم محمود ميّا \\ كمال سالم الحسنون \\ كلية العلوم || جامعة تشرين || سوريا
}

المستخلص: تضمنت الدراسة الحالية دراسة الطيف الغذائي لنوع من العوالق الحيوانية القشرية من رتبة Cyclopoida وهو النوع

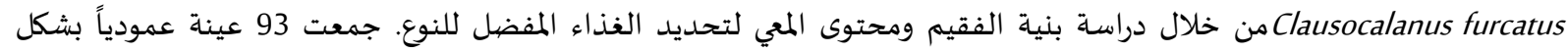

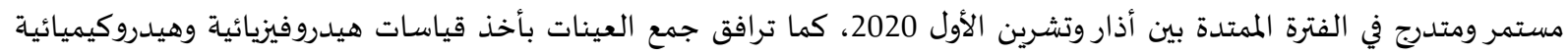

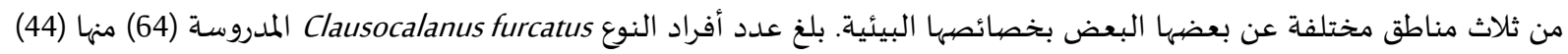

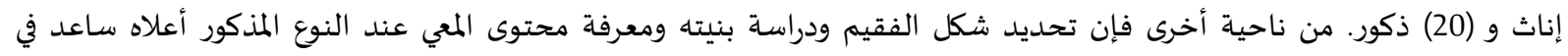
اتساع المعارف عن ظروف واستراتيجيات تغذيته تحت تأثير العوامل البيئية المختلفة، بلغ عدد العوالق النباتية التي تغذى عليها التيها النوع (9) Clausocalanus furcatus أنواع، منها (5) من السوطيات ونوعين من المشطورات ونوع واحد من مجموعة Cryptophyceae، كان أعلى متوسط للسوطيات (1755) فرداً، تلتها المشطورات(505) فرداً، ثم مجموعة الـ Cryptophyceae (189) فرداً. الكلمات المفتاحية: التخذية الطبيعية، الفقيم، محتوى المعي، القياسات الهيدروفيزيائية والهيدروكيميائية، استراتيجية التغذية. 


\section{Introduction:}

Crustacean zooplankton is a Heterotrophic and an important component of marine ecosystems (Al- Hanoun, Mayya, 2017) through the essential role playing in the food web (Siokou et al., 2002). It is a biological construction in which the feeding methods vary (Aleya et al., 2006), which increases the complexity and complexity of the food chain. in addition to that herbivorous group dependent on phytoplankton (Bottger, 2011), which creates a balanced biological composition (Guisande et al., 2002).

copepods are major components of marine food chains and operate either directly or indirectly as food sources for most commercially important fish (Sahar et al., 2020), and their oral appendices have evolved to suit the nature and quality of their food (Battuello et al., 2017). However, the jaw's leg movement to the mouth creates a flow of water that increases the pressure inside the mouth making the water enters with food (Lukasz, 2020), and others are equipped with a special filtration system through which it filters the food particles entering with Water stream (Mageed, 2006).

Copepods generally tend to feed on a mixed diet in their natural environment, especially in the first few layers (0- 50) m (Maps et al., 2014), and the survival and success of copepods over the years may be due to their ability to determine prey (Kang et al. (2002), and the selection of the preferred and most abundant food in the surrounding environment (Kim et al., 2012). It is worth noting, however, is the ability of many species of copepods to shift from a plant- feeding pattern in the absence of it in the medium to feeding on small animals and vice versa as is The case with Glausocalanus furcatus (Valeria et al., 2020).

Copepods are dominant creatures in marine zooplankton (Al- Hanoun, Mayya, 2017). Their diets often include large proportions of Bacillariophyceae that have Silesian structures to protect. Despite this protection, there are many species of copepods that are capable of breaking and shattering these structures with high efficiency even the most supported and protected species (Michels and Gorb, 2016). The structure and shape of mandible teeth at copepods also vary by species. Studies based on electron microscopy have illustrated that these teeth have complex microscopic composition containing silica and this explains their ability to destroy the structures of Bacillariophyceae (Abigail et al., 2020).

Various environmental factors such as temperature, salinity, dissolved oxygen, $\mathrm{pH}$, and transparency affect marine copepods and their nutritional activity (Lukasz, 2020), and the concentration and distribution of food particles in the surrounding medium (Brosset, 2019).

The research aims to study feeding for Clausocalanus furcatus determine the intestinal content of food, and study the shape and composition of its species, under the influence of various environmental factors.

The importance of economic research lies through clarifying the environmental and nutritional requirements of the studied species, which constitutes a basic rule that facilitates the prediction of the 
status of these species in terms of productivity, as they are of economic importance and constitute a major food for fish, crustaceans and many other marine creatures.

\section{Materials and methods:}

The species collection processes were carried out from the three study areas that were chosen in the coastal waters of the city of Baniyas in the Syrian waters, which differ from each other in environmental terms, as shown in (Fig.1), which are:

\section{Sanitation area: (A)}

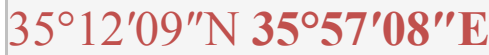

It is located opposite the Baniyas National Hospital, where the sewage of the hospital and the neighborhoods of Al-Morouj flows into a unified liquefaction line (a major sewage line), where its estuary ends in the coastal waters of a city, and this beach is away from the second area (the thermal station area) at a distance of $7 \mathrm{~km}$.

\section{The Thermal Station Area: (Estuary of hot water): (B)}

\section{$35^{\circ} 10^{\prime} 13^{\prime \prime} \mathrm{N} 35^{\circ} 55^{\prime} 21^{\prime \prime} \mathrm{E}$}

This region is located opposite the electrical power station in Baniyas, which is one of the five power stations responsible for supplying the country with electrical energy. The thermal plant is $5 \mathrm{~km}$ from the third clean area. The thermal water resulting from the cooling of the station and the steam of the boilers that unite with it is poured into marine waters.

\section{Prince Beach Chalets: (C)}

\section{$35^{\circ} 09^{\prime} 02^{\prime \prime} \mathrm{N} 35^{\circ} 55^{\prime} 20^{\prime \prime} \mathrm{E}$}

The Prince Chalets Beach, on which the Prince's Resort and Chalets is located, and this beautiful beach is $1 \mathrm{~km}$ from the Archaeological Tower of Al- Sabi site. This beach is a very clean area and not exposed to pollution, and therefore it is a destination for tourism and summer vacation. 


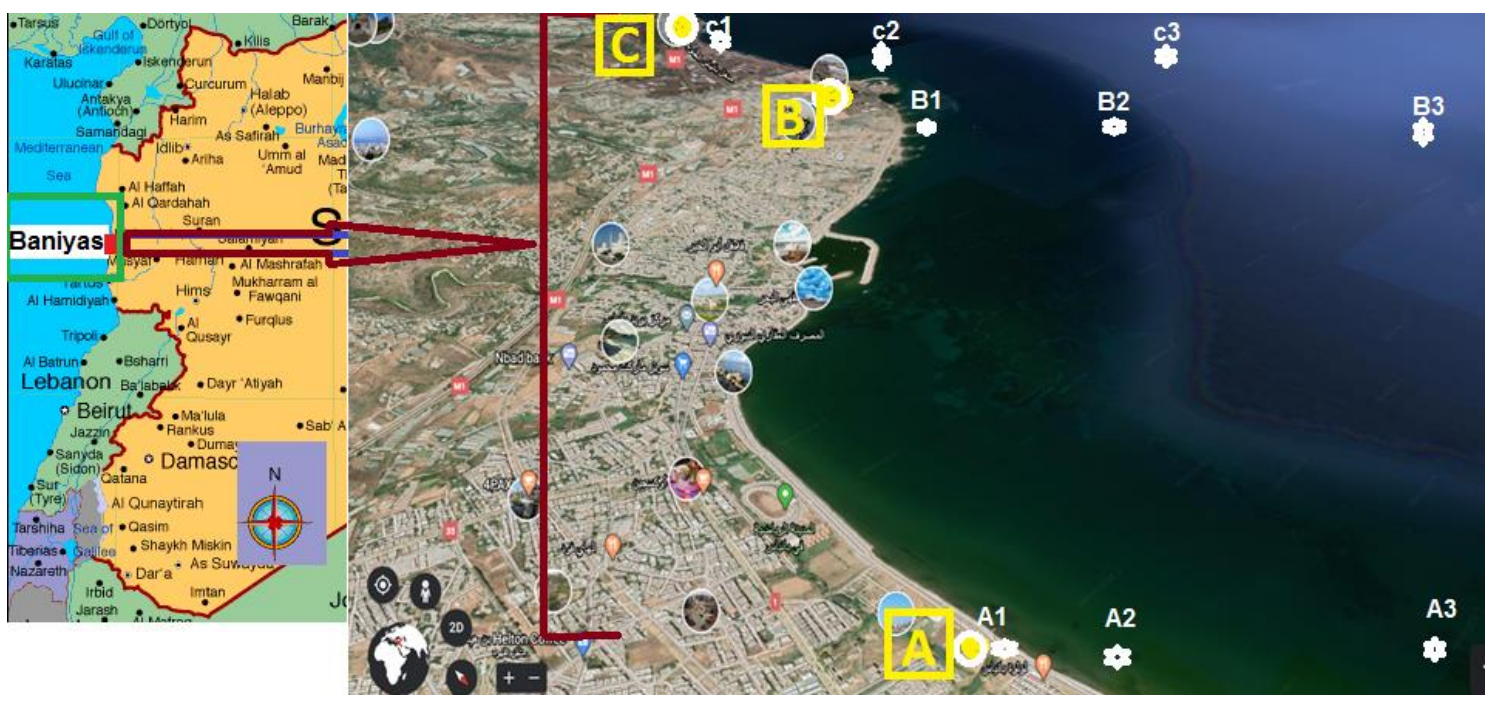

Fig. (1) Study areas in the coastal waters of the city of Baniyas.

Each region is divided into three sites (stations):

Zone A: Stations: A3- A2- A1.

Zone B: Stations: B3- B2- B1.

Zone C: Stations: C3- C2- C1.

The process of collecting samples of the two species in each site was as follows:

1- The first location: (50-0) m, (50- 25) m, (25-0) m.

2- The second location: (100-0) m, (100-50) m, (50- 25) m, (25-0) m.

3- The third location: (200- 0) m, (200- 100) m, (100-50) m, (50- 25) m, (25- 0) m.

Measurements were taken for the main environmental factors such as: (temperature $(\mathrm{t})$, salinity (s), dissolved oxygen concentration ( $\mathrm{O} 2), \mathrm{pH}$, transparency). For the combination process, a universal quantum network with a $200 \mu$ hole WP2 Closing Net with a locking device was used.

The following reference were used to classify the species Clausocalanus furcatus.

(Al- Hanoun, Zaeni, 2020).

The necessary graphs were created and the average calculation of the number of individuals in the gut of the studied species was calculated using a program Microsoft Excel.

\section{Results}

1- Taxonomic status and general description of the species: Clausocalanus furcatus

\section{1 -1 Taxonomic status}

Phylum: Arthropoda

Subphylum: Crustacea

Class: Copepoda

Order: Calanoida

Family: Clausocalanidae 
Genus: Clausocalanus (Giesbrecht, 1888)

Species: Clausocalanus furcatus (Brady, 1883).

\section{1 -2 Male}

The length of the male $(0.7-0.9 \mathrm{~mm})$ and in terms of its overall appearance is very similar to the female. The front end of the head was round, while the abdomen extended, and the fifth diplopia of the legs consists of an atrophied right leg, and a left leg consisting of four consecutive pieces. (Fig. 2).

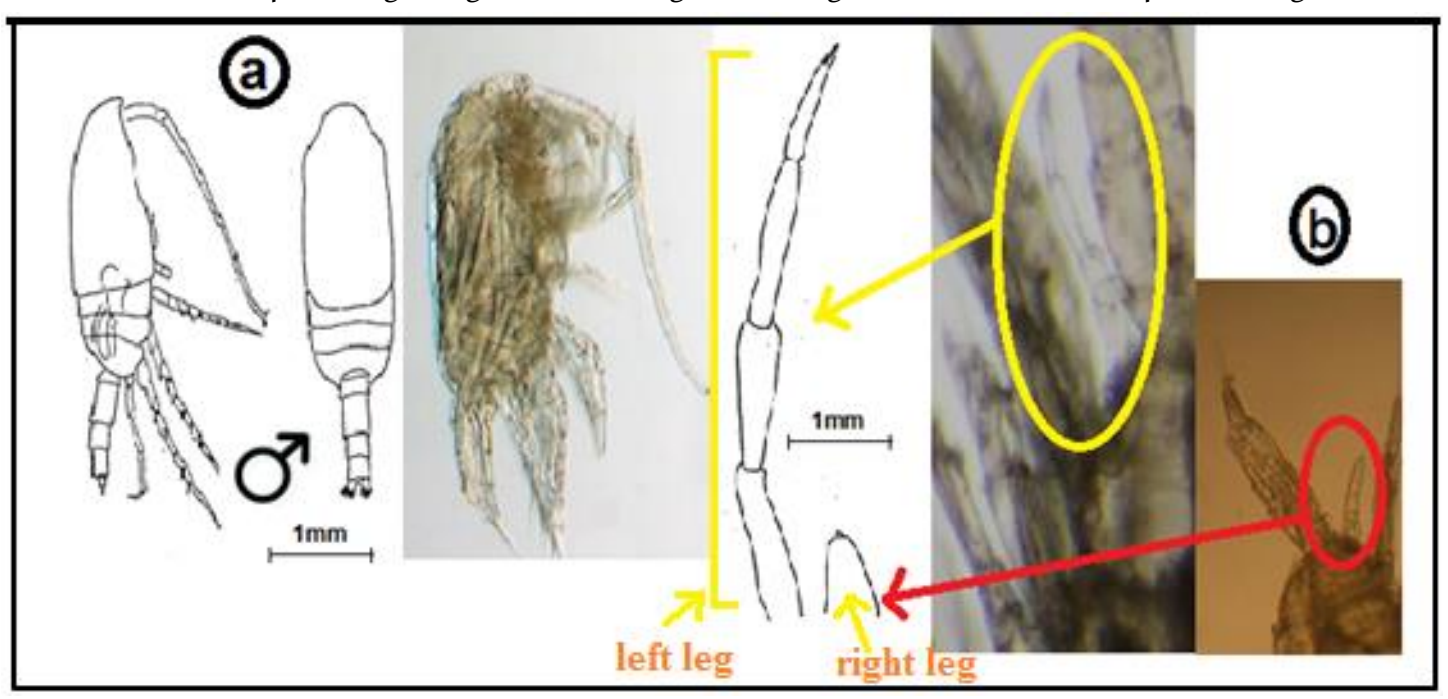

Fig. (2) (a) a general shape from the side to the male, (b) p5 of the male.

\section{1- 3 Female}

The length of the female (1.1-1.2mm), the front end of the head was round, fifth of the legs has a single branch and two parts (Fig. 3).

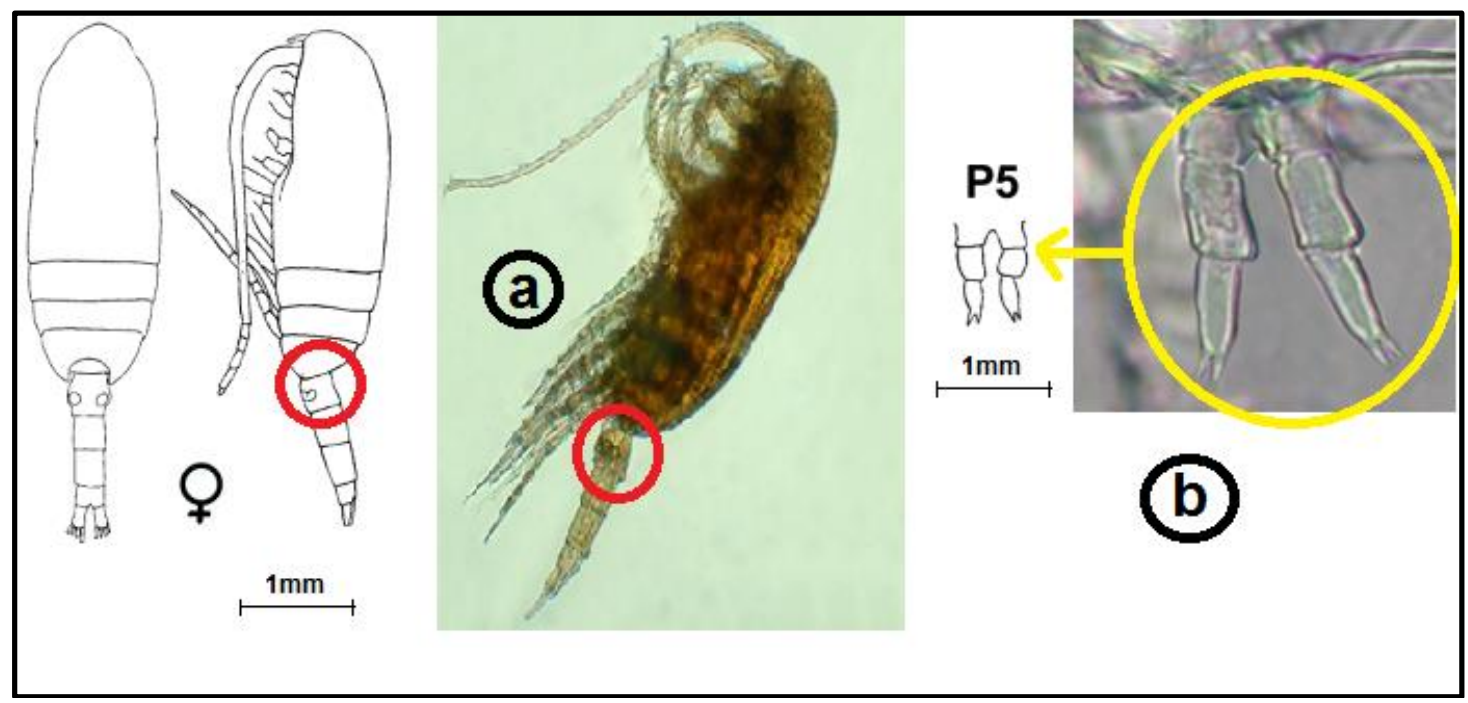

Fig (3) (a) a general shape from the female side, (b) p5 of the female. 


\section{2- Feeding of Clausocalanus furcatus:}

C.furcatus appeared in all study areas and stations, and the total number of individuals studied was (64) individuals, of which (44) are female and (20) male are distributed at different depths, and this explains that this species has a wide ecological adaptation with the values of environmental factors ( Eurybiont) as shown in Table 1 . The largest presence was in the layer with depth (0-50) $\mathrm{m}$, where the phytoplankton that exists Photosynthesis, The presence of marine currents and wave movement, and the exposure of the layer (0-50) $\mathrm{m}$ to significant changes in the values of environmental factors, as well as the Estuary drainage, whose water is loaded with organic materials and nutrients and which flows into station (A1), has made this layer a suitable place for the existence of the species Previous, and this species did not exist in station (B1) at all, and the reason is that this station is the mouth of the hot water resulting from cooling the turbine of the station and the boilers. Previous to bear it or even live in its field.

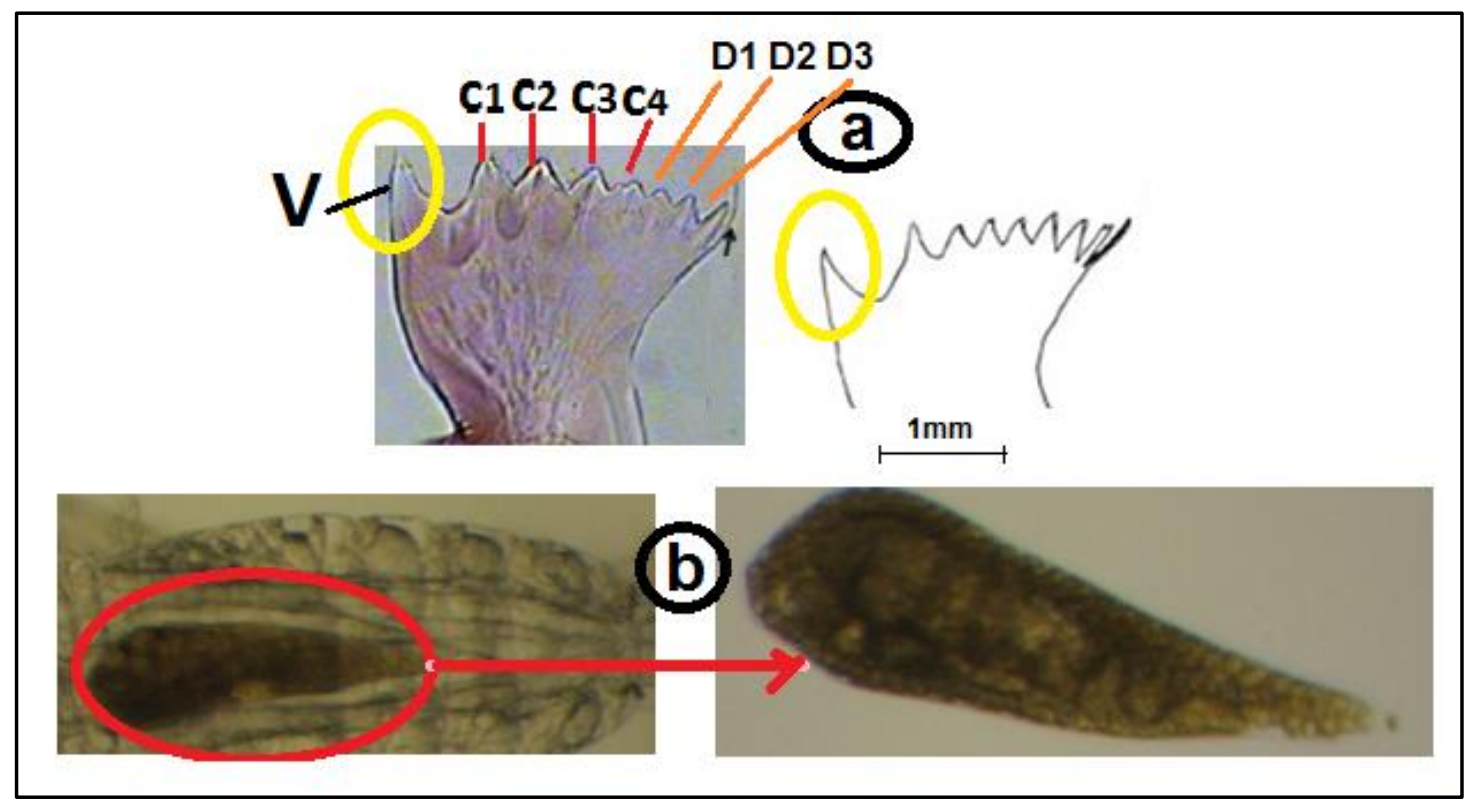

Fig (4) (a) mandible structure, Mandibular Gnathobasis V: Ventral Teeth. C1- C2- C3- C4: Central

Teeth. D1- D2- D3: Dorsal Tooth. (b) general view of the gut.

\section{Discussion}

It was found through this study, which was compatible with many international studies, that C.furcatus is herbivorous (Cornils, 2014), and maybe the most essential food for him is (Dinophyceae) (Todd et al. 2020) (Ibrahim, 2014), knowing that by studying the gut content for individuals of the previous species within the layer (50-0) $\mathrm{m}$, it was observed that there are several species of food and this explains that the previous species resort to mixed food due to the large number of nutrients in this layer, as it is the primary productivity layer, (And, 2004) and feeding on more than one species due to the high availability of food within them (Sota and Susuma, 2020), the large depths (200-100 m), it resorted to the use of only one species of food, according to what is available in the medium and most likely from Bacillariophyceae (Michels and Stanislav, 2015). The reason is that light does not reach those depths and 
phytoplankton does not exist to perform photosynthesis so, they are poor layers of food making species resort to dependence on food available in the medium (Sahar et al., 2020).

It was found through the current study that the layers with depths (50- 0) m, (50- 25)m and (15$0) \mathrm{m}$ are the richest layers for the phytoplankton species on which C.furcatus feeds, especially Dinophyceae, and the reason for this is due to the presence of light, and high appropriate temperature compared to the deep layers where there is no lighting and the temperature decreases, and thus phytoplankton, which is the main food of the studied species, is unable to exist and live at those depths (Todd et al., 2020).

Dinophyceae recorded the highest value, as the average number of (1755) individuals within the gut was at the species mentioned above, compared with the rest of the groups, these species are the main food of the studied species such as Ceratium platycorne, followed by the Bacillariophyceae (505) individuals in the gut, then the Cryptophyceae (189) individuals, these results were agreement with (Cornils, 2014).

It was observed through studying the gut structure of C.furcatus that its preferred species as a suitable food is Ceratium platycorne, and it was found that in the shallow layers it resorts to feeding on a number of species at the same time( Mayya, 2018), including the two species Ceratium palmatus and Ceratium reflexus, where the temperature is high and the salinity is low. (Tomonari et al., 2019), and occasionally feeding on Skeletonema costatum, Rhodomonas salina, Ceratium lunula, while it resorts to feeding on one species only, such as Bacteriastrum furcatum Shadbolt, in the deep layers due to low temperature and high salinity (Sota and Susma, 2020).

Thus, environmental factors, especially temperature and salinity, play an important role in changing the feeding conditions and strategies of the species, and study the adaptation of this species to the quantity and quality of food available in the surrounding medium (Tomonari et al., 2019).

C.furcatus diets include large proportions of Bacillariophyceae that possess protective silicic structures, and despite this protection, the former species is able to break and destroy these structures with high efficiency even the most supported and protected species of Bacillariophyceae (Valeria et al., 2020), and returns The reason for this is the mandible shape of the teeth $(4,3)$, which has short sharp edges that are used for grinding Bacillariophyceae and the rest of the phytoplankton species.

According to many international studies, which was done using an electron microscope, mandible teeth show a nano particular structure containing a little amorphous silica and a large percentage of crystalline silica that is spread in the form of a network of micro- ketonic fibers (Lukasz, 2020). It is also likely that these fibers will serve as the mainstay during the feeding process (Cornils, 2014), and the ventral tooth (V) (Fig.4) is the most important tooth in mandible at C.furcatus and at the rest of the copepods, especially Calanoida, which is the most important teeth varies according to species, on the other hand $(\mathbf{M x l})$ plays an important role in this species in preserving and holding food particles and 
preventing their exit as a prelude to their entry and push into the body of the organism (Sota and Susma, 2020).

The $(\mathbf{M x P})$ also play an important functional role for the previous species in particular and for copepods in general, through their movement with the presence of water currents in collecting food particles from the surrounding medium and surrounding them well and pushing them towards the inside of the body (Tomonari et al., 2019).

\section{Conclusion}

In the current study, we have collected zooplankton samples from the coastal water of Baniyas city (Syria) along with different hydrophysical and hydrochemical measurements. Those samples have been studied using a microscope to identify the shape and structure of the mandible and the content of the gut. The phytoplankton configuring the feeding of the studied species has also been defined. We found that Dinophyceae was the best feeding of this species. We also found that C.furcatus played a major role in marine food webs, as they formed the link between phytoplankton on the one hand and secondary consumers.

Table (1) Changes in the values of environmental factors during the period of emergence of C.furcatus during the study months.

\begin{tabular}{|c|c|c|c|c|c|c|}
\hline Depths $(\mathrm{m})$ & $\mathbf{0}$ & $\mathbf{2 5}-\mathbf{0}$ & $\mathbf{5 0 - 0}$ & $\mathbf{5 0}-\mathbf{2 5}$ & $\mathbf{1 0 0}-\mathbf{5 0}$ & $\mathbf{2 0 0}-100$ \\
\hline Temperature $\left({ }^{\circ} \mathrm{C}\right)$ & 29.05 & 24.64 & 20.21 & 19.01 & 9.56 & 8.02 \\
\hline Salinity \%o & 36.15 & 36.41 & 37.53 & 37.68 & 37.79 & 38.07 \\
\hline$(\mathrm{pH})$ & 6.71 & 7.22 & 7.49 & 7.67 & 7.70 & 7.89 \\
\hline Dissolved oxygen $(\mathrm{mg} / \mathrm{l})$ & 5.82 & 6.15 & 6.71 & 6.87 & 6.91 & 7.05 \\
\hline
\end{tabular}

Table (2) Some global studies that are compatible with the current study.

\begin{tabular}{|c|c|c|}
\hline History & Researcher & Study Title \\
\hline 2004 & And G. A. Paffenho“ Fer & $\begin{array}{l}\text { Relation of behavior of copepod juveniles to potential predation by } \\
\text { omnivorous copepods: An empirical- modeling study. }\end{array}$ \\
\hline 2004 & $\begin{array}{c}\text { Ricardo Giesecke } \\
\text { H.E. González }\end{array}$ & Mandible characteristics and allometric relations in copepods. \\
\hline 2013 & $\begin{array}{l}\text { Peter Tiselius } \\
\text { Enric Saiz } \\
\text { Thomas Kiørboe }\end{array}$ & $\begin{array}{l}\text { Sensory capabilities and food capture of two small copepods, } \\
\qquad \begin{array}{l}\text { Paracalanus parvus and } \\
\text { Pseudocalanus sp. }\end{array}\end{array}$ \\
\hline 2015 & $\begin{array}{l}\text { Jan Michels } \\
\text { Stanislav N }\end{array}$ & Mandibular gnathobases of marine planktonic copepods \\
\hline 2020 & $\begin{array}{l}\text { Abigail S. Tyrell } \\
\text { Houshuo Jiang } \\
\text { Nicholas S. Fisher }\end{array}$ & Copepod feeding strategy determines response to seawater viscosity. \\
\hline
\end{tabular}


Table (3) the species of phytoplankton that formed the food of C.furcatus during the study months.

\begin{tabular}{|c|c|c|c|}
\hline species & Taxonomic status & Depth (m) & Average number of individuals in the gut \\
\hline Ceratium contortus & Dinophyceae & $\begin{array}{c}25-15 \\
25-0 \\
50-25\end{array}$ & 213 \\
\hline Ceratium palmatus & Dinophyceae & $\begin{array}{c}25-0 \\
50-25 \\
100-50\end{array}$ & 320 \\
\hline Ceratium reflexus & Dinophyceae & $\begin{array}{c}25-15 \\
25-0 \\
50-25 \\
100-50\end{array}$ & 309 \\
\hline Ceratium lunula & Dinophyceae & $\begin{array}{c}25-0 \\
50-25 \\
100-50\end{array}$ & 289 \\
\hline Ceratium platycorne & Dinophyceae & $\begin{array}{c}25-0 \\
50-25 \\
100-50\end{array}$ & 331 \\
\hline Ostreopsis ovata & Dinophyceae & $\begin{array}{c}25-15 \\
25-0 \\
50-25 \\
100-50\end{array}$ & 293 \\
\hline Skeletonema costatum & Bacillariophyceae & $\begin{array}{c}25-15 \\
25-0 \\
50-25 \\
200-100\end{array}$ & 269 \\
\hline $\begin{array}{c}\text { Bacteriastrum } \\
\text { furcatum Shadbolt }\end{array}$ & Bacillariophyceae & $\begin{array}{c}25-15 \\
25-0 \\
50-25 \\
200-100\end{array}$ & 236 \\
\hline Rhodomonas salina & Cryptophyceae & $\begin{array}{c}25-15 \\
25-0 \\
50-25\end{array}$ & 189 \\
\hline
\end{tabular}

\section{References:}

1- Al- Arraj. L. (2017). Diversity and Copepods'composition of Moroccan Atlantic Coast (Northwest Africa), European Scientific Journal, 13(18): 272- 293. 
2- Aleya L., M. Michard, H. Khattabi, J. Devaux. (2006). Coupling of the Biochemical Composition and Calorific Content of Zooplankters with the Microcystis aeruginosa Proliferation in a Highly Eutrophic Reservoir. in: Environmental Technology, 27 (11): 1181 - 1190.

3- Al- Hanoun K.S., Zaeni.A. (2017). Theory of Zooplankton, Directorate of University Books and Publications, Tishreen University Journal, Syria. 17- 295.

4- Al- Hanoun K.S., Zaeni.A.(2007). Practical zooplankton, First Edition, Directorate of University Books and Publications, Tishreen University Journal, Syria. 25- 138.

5- Al- Hanoun K.S., Zaeni.A.(2020). Practical Book- Zooplankton- Second Edition, Directorate of University Books and Publications, Tishreen University publications. Syria- 276 p.

6- Avery DE, altland KK, dam HG. (2008). Sex- related differential mortality of a marine copepod exposed to a toxic dinoflagellate. Limnol Oceanogr, 53: 2627-2635.

7- Battuello, M., Sartor, R. M., Brizio, P., Nurra, N., Pessani, D., Abete, M. C., \& Squadrone, S. (2017). The influence of feeding strategies on trace element bioaccumulation in copepods (Calanoida). Ecological Indicators, 74: 311- 320.

8- Böttger- Schnack, R. (2011). Taxonomic re- examination and distribution of copepods reported as Oncaea notopus Giesbrecht, 1891 (Copepoda, Oncaeidae) in the Mediterranean Sea. Marine Biodiversity, 41: 325- 341.

9- Brosset, P., lloret, J., munoz, M., fauvel, C., van beveren, E., marques, V., saraux, C. (2019). Body reserves mediate trade- offs between life- history traits: New insights from small pelagic fish reproduction. Royal Society Open Science, 21: 214- 236.

10- Chen, M., Kim, D., Liu, H., \& Kang, C. K. (2018). Variability in copepod trophic levels and feeding selectivity based on stable isotope analysis in Gwangyang Bay of the southern coast of the Korean Peninsula. Biogeosciences, 15: 2055- 2073.

11- Cornils, A., \& Held, C. (2014). Evidence of cryptic and pseudocryptic speciation in the Paracalanus parvus species complex (Crustacea, Copepoda, Calanoida). Frontiers in zoology, 11: 1- 17.

12- D'Agostino, V. C., Hoffmeyer, M. S., \& Degrati, M. (2020). Morphology of the mandibular gnathobases of the copepods Calanus australis and Calanoides carinatus: Evidence of omnivory. Zoologischer Anzeiger, 286, 64- 71.

13- Giesecke, R., \& González, H. E. (2004). Mandible characteristics and allometric relations in copepods: a reliable method to estimate prey size and composition from mandible occurrence in predator guts. Revista Chilena de Historia Natural, 77(4), 607- 616.

14- Guisande, C., Maneiro, I., Riveiro, I., Barreiro, A., \& Pazos, Y. (2002). Estimation of copepod trophic niche in the field using amino acids and marker pigments. Marine Ecology Progress Series, 239, $147-$ 156. 
15- Ibrahim, A. M. M. (2014). Marine plankton and Genus Ceratium in the west coast of the Red sea. Blue Biotechnology Journal, 3: 295.

16- Jiang, H., \& Paffenhöfer, G. A. (2004). Relation of behavior of copepod juveniles to potential predation by omnivorous copepods: an empirical- modeling study. Marine Ecology Progress Series, 278: 225239.

17- Kaji, T., Song, C., Murata, K., Nonaka, S., Ogawa, K., Kondo, Y.,... \& Palmer, A. R. (2019). Evolutionary transformation of mouthparts from particle- feeding to piercing carnivory in Viper copepods: Review and 3D analyses of a key innovation using advanced imaging techniques. Frontiers in zoology, 16: 114.

18- Kang, Y. S., Kim, J. Y., Kim, H. G., \& Park, J. H. (2002). Long-term changes in zooplankton and its relationship with squid, Todarodes pacificus, catch in Japan/East Sea. Fisheries Oceanography, 11: 337- 346.

19- Khodami, S., Mercado- Salas, N. F., \& Arbizu, P. M. (2020). Genus level molecular phylogeny of Aegisthidae Gisbrecht, 1893 (Copepoda: Harpacticoida) reveals morphological adaptations to deepsea and plagic habitats. BMC evolutionary biology, 20:1-17.

20- Kim, Y.- O., Shin, K., Jang, P.- G., Choi, H.- W., Noh, J.- H., Yang, E.- J., Kim, E., and Jeon, D. (2012). Tintinnid species as biological indicators for monitoring intrusion of the warm oceanic waters into Korean coastal waters" Ocean Sci. J., 47: 161-172.

21- Komeda, S., \& Ohtsuka, S. (2020). New genus and species of calanoid copepods (Crustacea) belonging to the group of Bradfordian families collected from the hyperbenthic layers off Japan. ZooKeys, 951: 21- 35.

22- Lena Teuber, Anna Schukat, Wilhelm Hagen And Holger Auel. (2018) Trophic interactions and life strategies of epi- to bathypelagic calanoid copepods in the tropical Atlantic Ocean, Journal of Plankton Research, 36: 1109-1123.

23- Łukasz Sługocki. (2020) Variability Of Mandible Shape In The Marine Glacial Relict Eurytemora Lacustris (Poppe, 1887) (Copepoda, Calanoida, Temoridae), 93: 337-353.

24- Mageed, A. A. (2006). Spatial- Temporal variation of zooplankton community in the hypersaline lagoon of Bardawil, north Sina- Egypt". Egyptian Journal of aquatic research, 32: 186- 193.

25- Maps, F., Record, N. R., \& Pershing, A. J. (2014). A metabolic approach to dormancy in pelagic copepods helps explaining inter- and intra- specific variability in life- history strategies. Journal of plankton research, 36: 18- 30.

26- Mayya W.M., (2018) "Taxonomical and Ecological study of crustacean zooplankton (Arthropoda) in the coast water of Tartous City" M.Sc.thesis, Department of biological science in environment and animal classification, University of Tishreen.184p. 
27- Michels, J., \& Gorb, S. N. (2015). Mandibular gnathobases of marine planktonic copepods -feeding tools with complex micro- and nanoscalecomposite architectures, Beilstein Journal Of Nanotechnology, 6: 674-685.

28- Michels, J., \& Gorb, S. N. (2015). Mandibular Gnathobases of Marine Planktonic CopepodsStructural and Mechanical Challenges for Diatom Frustules. In Evolution of Lightweight Structures. Springer, Dordrecht, 59- 73.

29- Sano, M., Maki, K., Nishibe, Y., Nagata, T., \& Nishida, S. (2013). Feeding habits of mesopelagic copepods in Sagami Bay. Progress in Oceanography, 110: 11- 26.

30- Siokou- Frangou, I., Bianchi, M., Christaki, U., Christou, E. D., Giannakourou, A., Gotsis, O.,... \& Zervakis, V. (2002). Carbon flow in the planktonic food web along a gradient of oligotrophy in the Aegean Sea (Mediterranean Sea). Journal of Marine Systems, 33: 335- 353.

31- Tiselius, P., Saiz, E., \& Kiørboe, T. (2013). Sensory capabilities and food capture of two small copepods, Paracalanus parvus and Pseudocalanus sp. Limnology and Oceanography, 58: 1657- 1666.

32- Tyrell, A. S., Jiang, H., \& Fisher, N. S. (2020). Copepod feeding strategy determines response to seawater viscosity: videography study of two calanoid copepod species. Journal of Experimental Biology, 223(13).

33- Wolny, J. L., Egerton, T. A., Handy, S. M., Stutts, W. L., Smith, J. L., Whereat, E. B.,... \& Deeds, J. R. (2020). Characterization of Dinophysis spp. (Dinophyceae, Dinophysiales) from the mid-Atlantic region of the United States1. Journal of phycology, 56: 404- 424. 